\title{
Secularism, Utopia and the Discernment of Myth
}

\section{Roland Boer}

Is spiritual experience the best way to account for the host of newer religious sensibilities that are cropping up, in enabling the crossing of borders between older religious systems that scatter the cultural landscape as the newer intolerances that have taken their place? In order to offer a theoretical angle on the question of spiritual experience I want to deal with four issues: secularism, post-structuralism, the utopian possibilities of religion, and what I want to call, following Ernst Bloch (1972), the discernment of myths.

The specific issue relating to post-secularism is the widespread denigration of "religion" in favor of "spirituality." No one, it seems, wants to be religious any more; no one, in fact has been religious for a good time now; in popular parlance, worship halls reek of incense gone rancid, moth-eaten robes, and empty temples, whether Jewish synagogues or Hindu stupas. However, what one can be is spiritual, removed from any institutional taint, free to pick up lost forms of spirituality or any variety of the new forms that spring up daily. If I add that spirituality now is characterized by bricolage and eclecticism, that it expresses a deep desire to be free from political as well as institutional taint, then we have a definition of spirituality. It is, in other words, the properly late capitalist and consumerist approach to religion. The popularity and valorization of the spiritual is so often taken as a mark of the new post-secular order, and religion has become the bogey term. The seemingly rapid appearance of such a distinction hit me while teaching in 1999. In a course entitled "Culture, Religion and Spirituality" I found that not one of the students in the course would admit to being religious: if they were anything, it was spiritual,

Roland Boer is Reader in Comparative Literature and Cultural Studies at Monash University, Australia. His research and writings concern philosophy, politics and the Bible. Among many articles and books publications, he has published Marxist Criticism of the Bible (2003) and has in press the books Symposia (Equinox), Criticism of Heaven (Brill) and Political Myth (Duke). 
and that ranged from to indigenous spirituality to the notion that all the great religious leaders (Zoroaster, the Buddha, Jesus, Mohammed, etc.) arrived and departed on a passing comet to the usual crystals and pyramids and conservative Christian churches.

The utopian dimension of my title refers to the desire to find or develop a shared language of spiritual experiences that does not ride roughshod over cultural difference. It seems to me that, ironically, one of the most neglected areas of the study of religions or of spiritualities is that of utopia, for religions contain a vast wealth of utopian images, hopes and aspirations. This leads to the essay's final topic, the discernment of myths, since if we are to undertake a utopian hermeneutics of religious traditions or spiritual experiences, then a crucial task is the discernment of those myths. Here I assume that religion and spirituality inevitably deal in the realm of myth: those that are repressive, violently intolerant, racist, and misogynist, as well as those that offer resistance to such repressions and hint at alternative possibilities.

\section{Secularism and Post-Secularism}

The new spirituality is often taken to be a mark of post-secularism, but that begs the question of post-secularism itself and its relation to secularism. I am thinking here of the problems concerning any such distinction: whether the "post" signifies a temporal distinction; or whether the notion of post-secularism, itself a debated term, offers a critical perspective on secularism; or whether post-secularism itself is constituted by a new awareness, one after the fact, as it were, of the whole debate concerning secularism. My preferred approach is the last one, for as with the awareness of realism or modernism, the moment of such awareness, the ability to speak about and criticize a certain moment of cultural production, marks a shift to another position. But this understanding of post-secularism means that it is dialectically connected with secularism, that the two cannot be understood without each other in a complex relationship. It seems to me that this dialectical relationship operates by means of contradictions, post-secularism thereby showing up the contradictions within secularism itself. In what follows I trace the contradictions of secularism in order to show how post-secularism constitutes the working out of such contradictions.

More than the ban of priestly hocus-pocus and enforced ignorance, what we now assume to be secularization - the gradual removal of religion - was itself a debated term in the nineteenth century until the theories of Max Weber and Karl Löwith began to dominate, which are of course the ones we tend to ascribe to now. But there were other theories of secularization. Let me take as an example that of Walter Benjamin, whose interpretation in The Origin of German Tragic Drama idiosyncratically converted Weber's thesis in The Protestant Ethic and the Spirit of Capitalism as well as Löwith's in From Hegel to Nietzsche: The Revolution in Nineteenth-Century Thought. For Benjamin, secularization was the fall away from historical - that is, theological - time, into space and spatialization, an inauthentic and excessive shift under the influence of the natural sciences. Over against theological or messianic time, Benjamin described this dehistoricized and spatialized 
time as "natural history," marked by classification, taxonomy and topology (see Hansen 1998). In many respects Benjamin illustrates the issue at stake in secularization, namely that the criticism of religion that continues today is in a very specific sense the criticism of Christianity as the most dominating form of global religion. In other words, the ban on religion was in fact a ban on Christianity, for secularization itself was both enacted and theorized in a Europe steeped in Christianity.

The nature of this debate over secularization, upon which I have touched all too briefly, points to a feature of the term religion itself. In the studies of religion - the preferred term among most university departments or programs over against theological colleges with their explicit theological agendas - religion is often understood as the generic term for the beliefs and practices relating to the ultimate reality or supramundane realm, beyond everyday human experience. However, religion as a term has its own peculiar history that belies such a generic meaning. I am not so much interested in the Latin origins of the term - re-ligio, or "binding back" - but in the work of the early theorists of religion such as James Frazer and F. Max Muller. Frazer"s multivolume study, The Golden Bough (1925-30), still appears in its abbreviated form as reprints in bookshops, whereas Muller"s translations of Hindu and Buddhist texts in the Sacred Texts of the East (1883-1910) ran on well beyond his own work to include a whole range of Hindu, Buddhist and Muslim texts that still appear in the odd library. Both gathered their material, which might best be described as enormous catalogues or inventories, from the accounts of missionaries, travelers and the early entrepreneurial traders. The impact of their work on an emerging capitalist Europe was immense, showing the extraordinary wealth and diversity of religious belief and practice in the so-called new lands that were continually being "discovered." But they cast the material they gathered, however bowdlerized, misrepresented and truncated it might have been, in terms and categories that were fundamentally Christian. It is not so much that they used the major categories of theology - harmatology, anthropology, Christology or eschatology but that the structures of Christianity, its institutions, the distinction between belief and practice and so on, became the organizing principles of their work. Thus, all Frazer's focus on the so-called fertility myths in which the key god or goddess dies and then rises in a perpetual cycle was determined by the patterns of the Christian liturgical calendar with its cycle from advent through Christmas, Epiphany, Lent, Easter, Pentecost, ordinary time and then back to Christmas again, in which the year follows the birth, death and resurrection of Christ. In a similar fashion, William Robertson Smith's still influential theory of sacrifice - that it contains two moments of propitiation of the god or gods and then communion when the worshippers share between them and their god(s) the body of the sacrificial victim - draws its material from the Hebrew Bible (Old Testament). This should come as no surprise, given Robertson Smith's former life as a lecturer in Old Testament in the Free Kirk of Scotland.

This is not a particularly new argument - that the term religion is indelibly understood in Christian terms - but I want to draw two points from it. First, the development of the whole area of the study of religions is part of the secularization process itself, which can now be understood as the transition of categories from Christian 
thought and practice into all of those new areas that built themselves up through the rejection of Christianity. Whether we think of the role of Christianity in the development of the sciences or of the study of literature, the forms, categories and questions asked were derived from Christian theology and biblical practice while the content itself was denied and rejected. Christianity was, in other words, the enabling force, the absent cause of these secularized disciplines and realms of social and cultural life. So also with the study of religion, which became the study of religions other than Christianity in Christian terms.

Lest we think of this as a benign process I want to pick up Adorno's criticism of secularization, especially the secularized theology that he found in Kierkegaard, Heidegger, existentialism, liberal theology more generally and metaphysics. Let me take the example of existentialism: in part due to the centrality of Kierkegaard in existentialism, Adorno finds the theological residue (Kierkegaard being primarily a theologian) of existentialism poisonous. Its "“addictions' have seeped into the language," a language which "molds thought" (Adorno 1965, 8). And this is the problem: it is not as though the content floats free of its container, language, but that language itself has its own shaping, content-producing function. The language of theology, appropriated by Heidegger and existentialism, has the distinct ideological role of producing patterns of subordination to an absolute authority, which became fascism rather than God and the Church. The theological language of existentialism - which drew its sacredness from the cult of authenticity rather than Christianity - becomes, for Adorno, an ideological schema particularly suited to fascism, for which it functioned not so much as an explicit statement, but as a "refuge," a mystification that gave voice to an ostensible salvation from alienation that functioned as a virulent justification of oppression, the "smoldering evil" (Adorno 1965,9) of fascism. Adorno would repeat this move at various points in his work. For example, he shows how a critique of idolatry that lies at the heart of the famous ban on images (Bilderverbot) of the second commandment in Exodus 20. The ban on images, or as Adorno transmuted it philosophically, das Nichtbegriffliche, the "non-conceptual," works its way through Negative Dialectics and Aesthetic Theory, but Adorno develops his famous criticism of the concept through the critique of idolatry that is at the heart of the ban itself. In other words, if you get rid of theology and its authority structures, i.e. God, but continue to use its structures and ways of thinking, then the authority and power that formerly rested with god or the gods is transferred to something else - a philosophy, political figure, a cause or passion - all of which become so many idols. The full circle comes with the study of other religions, where instead of surreptitiously replacing god with something that does not have the traditional trappings of the divine, you begin to replace one god with another in an endless pattern. That the new gods appearing on the horizon have the contours of the God you have just left behind: the dogmas, images, institutional structures and conceptual apparatus of Christian theology.

Secularization then becomes a process riven with contradictions, one whose rejection of Christianity relies on Christianity, and this, I would suggest, is one of the main reasons for the fact that secularization never quite seemed to succeed - as 
in the radical separation of church and state in the United States where religion ends up saturating the state, or in France where the state takes over the role of moral arbiter and ends up banning Muslim headscarves. The long held expectation of the eventual decline and disappearance of religion that is characteristic of both Marxism and liberalism, never quite took place. And it is this contradiction that unfolds in what is now called post-secularism. Now, that religion carries with it the bad odor of the whole history of secularization. The flowering of the myriad forms of religious expression and experience for which the secularization hypothesis could not account is instead described in terms of spirituality, the properly postsecular religion. I don't want to trace the Christian history of the term "spirituality," but one of its features is that it relies upon the widespread knowledge of a whole range of religious practices that would not have been possible without the study of religions in the first place, without the endless cataloguing and study of religions from the most ancient, such as Sumeria and Babylon or pre-historic humans, to the most contemporary forms, such as the well-known Heaven's Gate group that committed suicide, all shod with Nike shoes, when the comet Hale-Bopp appeared on earth's horizon. Apparently emptied of doctrines to which one must adhere, or of institutions that carefully guard salvation, or of specific groups bound by language and ethnic identity, spirituality enables one to recover lost or repressed practices, such as Wicca or Yoruba sacrifice, but to pick and choose elements that seem to suit individual lifestyles or predilections. It allows one to designate the vitality of indigenous religions (which are no longer religion but spirituality), as a lost source of connectedness with the land, with nature, or other human beings. Unfortunately, however, spirituality's private piety and devotion comes at the expense of any collective agenda. It also relies on both liberal pluralism and tolerance, as well as the profound reification of social and cultural life that is everywhere around us. You can practice your own particular spirituality in your small corner, as long you don't bother me, we say. Like secularization, spirituality itself depends upon its own contradiction: both rely upon the religion they reject.

\section{Utopia}

But have I not been a little too negative, too critical of spirituality? I am not interested in an apology neither for the older notion of religion - that should be clear enough - nor even for the institutional life of a marginalized Christianity. But what I do want to do is pick up the second aspect mentioned above, namely utopia. For I want to follow Ernst Bloch, for whom the moment of ideological suspicion is incomplete without a utopian hermeneutics, or a hermeneutics of recovery (although I prefer utopia over recovery for reasons that will become clear below.) What is often forgotten is that the hermeneutics of suspicion and recovery in political approaches such as feminism, post-colonial criticism and liberation theology owe a debt to Bloch. It seems to me that the effort to locate a shared language of "spiritual experience," one that is sensitive to variations of social, political and cultural difference, relies upon a utopian project in the best sense(s) of the term. However, before I pursue this part of my argument, let me say a few things about such a utopian hermeneutics. 
Bloch's lifelong project was the recovery of the very idea of utopia, drawn from the Bible itself, particularly when it had been successfully relegated to the realm of the dreamy and impractical. Through many detours and byways, both physical and mental, Bloch winds his tortuous way around the question of what it means to have hope. We might distinguish between the philosophical, hermeneutical, literary and aesthetic dimensions of Bloch's utopian project. As for philosophy, utopia becomes a philosophical principle that Bloch was able to lift from the literary text and cast over any object, cultural, political, sacred or economic. In doing so, Bloch sought to answer the tendency for utopias to regress, to long for a lost golden age. In these regressive utopias there is a contradictory process of forgetting and remembering: the past becomes the basis for utopia by means of denying the role of the past in determining the present system against which the utopia is posited. In other words, the future is but a return to pristine origins, bypassing the undesirable present. When utopia and restoration become identical, one has the hallmarks of regressive and reactionary utopias (which eventually reveal themselves as dystopias.) Over against the longing for a restored past, Bloch argued for a basic orientation to the future as characteristic of utopian thought, of the human psyche and society. If there is a utopian moment in what is felt to be the past - Eden or Paradise, the secret guild of masons who look back to Solomon's temple as the ideal model, the Island of the Blessed, Atlantis, and so on - then the energy for that moment derives not from the past, according to Bloch, but from the utopian vision of the future. He sought a discovery of the future in the past, understood in the sense that what may have begun in the past requires the future for its completion. The central philosophical category in Bloch's system is therefore the future, the novum, a radical openness to a future that cannot as yet be imagined, formulated, or even spoken about.

Alongside the philosophical category of the future, where one can debate the relative truth claims of different utopias, there is also the hermeneutical category. As opposed to the philosophical, a utopian hermeneutics seeks the various unexpected utopian fragments and glimpses in the ruins of the present. In all its multifarious forms, this is the thread that runs through the whole corpus of writing, a hermeneutics that searches everywhere - in literature, folklore, myth, architecture, nursery rhymes, popular culture, music, of all ages and places - for the hope of a better world. For Bloch it is less a particular doctrine of thought than a hermeneutical strategy in itself, a frame of reading that locates utopia even in the worst ideological and cultural products available. In such a dialectical strategy many negative and unredeemable items turn out to conceal a positive and utopian moment. In other words, the negative is crucial for the presencing of the positive: only by means of an oppressive moment can the positive emerge. Yet even the moments that presage a utopian future do so not through their immediate content but through their finite nature. Hope drives forward less through the future that is anticipated than by dissatisfaction with the present. Further, Bloch's continual and irrepressible desire was to read all he came upon as in some way marked by a utopian desire, a repressed wish for another, better world.

I want see whether the desire to develop a shared language of spiritual experi- 
ence may also be understood in a utopian fashion. Does this get us away from the institutional traps and cul-de-sacs of religion that seem to close down so many efforts at crossing the boundaries? One of the problems, it seems to me, is that religions present us with mutually exclusive world-views. But I am anticipating an argument to which I will turn in a few moments. Does spiritual experience get us beyond these problems? In short, I don't think so, unless the terms are radically emptied of their old meanings and loaded up with new ones (something I think is not possible either). There are too many problems with the notion of "spiritual," let alone "experience." First, spiritual experience cannot be understood outside the mediating influence of its institutional, cultural and historical situation. We can't shed these to find ourselves left with an unmediated experience. Second, the notion of spiritual experience itself has a distinct history in Western Christian thought. One of its most influential theorists, Rudolph Otto (1929), argued in what is still an influential text, that the signs of encountering the Other, the mysterium, are feelings of awe and wonder, tremendum et fascinans. But Otto was writing in a context influenced by the long tradition of German piety, and while he tried to develop a theory that was not explicitly Christian, it works very well as a way of understanding the Christian encounter with God. Third, as I have already suggested, spiritual experience relies too much on both empiricist assumptions regarding experience (the domain that is most true and therefore not to be questioned) and the valorization of the individual person.

Have I left Bloch behind in my criticism of "spiritual experience"? Is there no utopian dimension to the effort to speak one language, or at least one that is open rather than closed? Rather than spiritual experience, a more fruitful approach is the question of myth. If the post-secular era has brought to our attention a whole spate of new spiritualities, then it has also brought myth back onto the agenda. Most importantly, myth is the language both religions and spiritualities speak.

Even more than religion per se, the Enlightenment target of secularization was myth, a term that had acquired an unwieldy cluster of associations: untruth, confusion, fuzzy thinking, the ideology of oppression, and so on. Myth found itself driven from town to town, expelled by the enlightened burghers, only to retreat to the forests and deserts, the realm of Nature, where a few wayward individuals might have some use for it. Faced with the use of myth by the Nazis and other sundry fascists, with their notions of blood and soil and the Blond Beast, Walter Benjamin and Theodor Adorno saw only the negative aspects of the term. For Benjamin, the ultimate form of myth was capitalism, as he traced in The Arcades Project (1999), and so he sought a way beyond myth, a waking from the dream, that made use of biblical motifs. Unfortunately, he remained trapped within the myth of the Bible itself. For Adorno (1999), myth was the antithesis of utopia. Myth was the realm of the unitary principle, the abolition of non-identity that is characteristic of a world dominated by men. For both Adorno and Benjamin, utopia meant the end of myth.

\section{The Discernment of Myth}

From my perspective, Bloch provides a far more satisfactory approach to myth. I want to pick up his strategy of the discernment of myth, a dialectical reading that 
neither throws myth out wholesale nor takes myth as a positive dimension of human culture. For Bloch, myth is neither pure false consciousness that needs to be unmasked, nor a positive force without qualification. Like ideologies, all myths, no matter how repressive, have an emancipatory-utopian dimension that cannot be separated from deception and illusion. Thus, in the very process of manipulation and domination, myth also has a moment of utopian residue, an element that opens up other possibilities at the very point of failure. Bloch is particularly interested in biblical myth, for the subversive elements in the myths that interest him are enabled by ideologies both repetitious and repessive.

Bloch's most lucid discussion of the role of myth comes in his debate with the radical theologian Rudolph Bultmann, who proposed a program of demythologization of the Bible and theology. In place of a program such as Bultmann's, Bloch - no stranger to myth, fairy-tale and related genres - feels that it is the purpose of such materials that counts rather than the pre-scientific ideas they contain. Do they speak of transformation and liberation? Do they have cunning heroes who win through a ruse? But this requires some distinction within the broad category of myth - too often a blanket term without specificity, lumped together by Marxists and others in Angeles's phrase, "the imbecility of the primeval forest" (Bloch 1985, vol 9,339) - between the despotism and domination of myth proper and myths that, like later fairy-tales, subvert such domination (see also Bloch 1988, 163-85). The story of Prometheus in Greek mythology, or of the serpent in Paradise in the Bible, gives voice to this "fairytale" element in. I think Bloch would much prefer to keep both the conformist and non-conformist elements of myth rather than no myth at all, since the banishment of myth discards the "joyful message," the "deepest utopian theme" (Bloch 1985, vol 9,343) of mythology along with all that is oppressive.

If the first step of his argument is to seek out the purpose of myth in order to make a political distinction, his second step involves distinguishing further between types of myth. In part, this is because Bloch does not want a wholesale recovery of myth, for this would render him an anti-Enlightenment thinker beyond the wide circle of Marxism. So fear, ignorance and superstition may go, but give expression of the quality and wonder of nature should not. Fairy tale, legend, saga and myth become separate entities (see also Bloch 1985, vol 9,344-5). By invoking Greek art, science (Kepler) and the Romantics, Bloch is processing myth through dialectics - "destroying and saving the myth in a single dialectical process" (Bloch 1985, vol 14,67).

At his best, Bloch's discernment of myth is an extraordinary approach, for it enables us to interpret the myths of any religion or spirituality as neither completely reprehensible nor utterly beneficial. That is to say, it is precisely through and because of the myths of dominance and despotism that those of cunning and nonconformism can exist. It is not merely that we cannot understand the latter without the former, but that the former enables the latter. Let me conclude with two examples of the discernment of myth drawn from Bloch's reading of his favored text, the Bible. The first concerns Eden and the second death. Eden is for Bloch a paradigm for utopia (Bloch 1995, 758-94). The point of discernment here is that Eden is not so much a story of some ideal state in the past that is forever unattainable but an image of the future for which we strive. After seeking Eden, he concludes: "Eldorado- 
Eden therefore comprehensively embraces the other outlined utopias" $(1995,793)$. But Eden cannot be separated from the idea of a Promised Land, which he suggests precedes the Babylonian garden story borrowed by the Israelites, nor from the New Jerusalem, when Eden will be restored. But Bloch is interested in the way Eden remains a physical, geographical space, a garden to which entry is forbidden though searching for it and living close by are permitted. This unfallen natural space is remarkably mobile, often connected with other legends, but Bloch finds it in Jerusalem, (in Dante), India (in the broadest possible sense), Prester John's Indian kingdom, the voyage of St Brendan and St Brendan's Isle, in the Atlantic (which was often read as India), in what drove Columbus (who believed that close to his newly found "India" was Paradise, which would soon lie within Christendom,) in the south land, terra australis, in the icy north of the kingdom of Thule, within the Earth and beyond the stars.

If Eden seems obvious as a utopian paradigm, then Bloch's deliberations over death show his discernment of myth at full power. They are among the most honest of any secular thinker that I have seen: for Bloch, "death depicts the hardest antiutopia" (Bloch 1988,9). As "a highly inadequate end, generally breaking, only very rarely rounding off, the human life" (Bloch 1972, 249), it saps the energy of anyone who sets out to change the world. Eschewing a solution in a collective notion of continued life, Bloch distinguishes between the act of dying, which is itself part of life, and death as the resultant state. The former generates the odd apprehension, but the mythical status of death engenders sheer horror. So Bloch seeks to cut through this mythology to locate a source of courage in the look forward to the Novum. He does nothing less than recast the myth of death as a departure, an open question. Interested in neither the "positive dogmatism" of Christianity nor a materialist "dogmatic negativity," he comes out as an agnostic regarding death: the journey is simply an unknown, and anyone who attempts to say what actually takes place has another agenda. Rather than the traditional image of the resurrection to a new life or indeed the retrospection that immanent death produces, he stresses that death should be regarded as an open question for which we have no answers. Atheism, therefore, does not preclude the possibility of something beyond death, for "the status viae lies far beyond death, which hardly represents an inflexibly formative status termini" (Bloch 2000: 265).

In the end, then, the value of religions like Christianity is that they have tapped into this utopian desire for something beyond death. Their mistake for Bloch is that they want to say something definite about death. But that something is hardly definite: it is mythology, and for that we need a discerning eye that can see both the liberating and repressive features of those myths.

\section{Conclusion}

If we follow through the dialectical relationship between secularism and postsecularism - a contradictory logic in which secularism turns out to rely on the Christianity it everywhere denies, a logic that appears starkly in a post-secularism that cannot be thought without secularism - then myth turns out to be the most urgent religious or spiritual question for us. Rather than the problem-ridden term 
"spirituality", I have argued that Bloch's hermeneutics of the discernment of myth provides not only a productive method, but also an approach to the utopian desire that lies behind any effort to find a shared "religious" or "spiritual" language. Such a language needs to be both critical and appreciative, for myths work in an extremely cunning fashion. It is a process that enables on the one hand the identification of those myths, or even elements within a myth, that are oppressive, misogynist, racist, that serve a ruling elite, and on the other, those which are subversive, liberating and properly socialist or even democratic - in other words, utopian.

\section{Works Cited}

Adorno, Theodor W.. Jargon der Eigentlichkeit; Zur deutschen Ideologie. Frankfurt am Main: Suhrkamp Verlag, 1965.

---. The Jargon of Authenticity. Trans. Knut Tarnowski and Frederic Will.

Evanston, Ill: Northwestern University Press, 1973.

---. Negative Dialectics. Trans. E. B. Ashton. London: Routledge, 1990.

---. Aesthetic Theory. Trans Robert Hullot-Kentor. Minneapolis: University of Minnesota Press, 1997.

---. Dialectic of Enlightenment (with Max Horkheimer). Trans. John Cumming. New York: Continuum, 1999.

Benjamin, Walter. The Origin of German Tragic Drama. Trans. John Osborne. London: Verso, 1998.

---. The Arcades Project. Trans. Howard Eiland and Kevin McLaughlin. Cambridge, MA: Belknap, 1999.

Bloch, Ernst. Atheism in Christianity. The Religion of the Exodus and the Kingdom, Trans. J. T. Swann; New York, Herder and Herder, 1972.

---. Werkausgabe.16 volumes. Frankfurt am Main: Suhrkamp, 1985.

---. Utopian Function of Art and Literature: Selected Essays. Trans. Jack Zipes and Frank Mecklenburg. Cambridge, Massachusetts: MIT Press, 1988.

--- The Principle of Hope.Trans. N. Plaice, S. Plaice and P. Knight. Cambridge, Massachusetts: MIT Press, 1995.

---. Literary Essays. Trans. Andrew Joron and others. Stanford: Stanford University Press, 1998.

---. The Spirit of Utopia. Meridian. Stanford, CA: Stanford University Press, 2000.

Boer, Roland. Marxist Criticism of the Bible. London: Continuum, 2003.

---. The Criticism of Heaven. Leiden: Brill, Forthcoming.

Bultmann, Rudolph. Theology of the New Testament. London: SCM, 1952-55.

Docker, John. 1492: A Poetics of Diapora. London: Continuum, 2001.

Eliade, Mircea. The Myth of the Eternal Return. Trans. Willard R. Trask. New York: Pantheon, 1954.

---. Myth and Reality. London: Allen and Unwin, 1964.

Frazer, James. The Golden Bough: A Study in Magic and Religion. 12 volumes. London: Macmillan, 1925-30.

Hanssen, Beatrice. Walter Benjamin"s Other History: Of Stones, Animals, Human Beings, and Angels. Berkeley, CA: University of California Press, 1998. 
Lévi-Strauss, Claude. The Savage Mind. London: Weidenfeld \& Nicolson, 1966.

---. The Raw and the Cooked: Introduction to a Science of Mythology. London: Random House, 1994.

Löwith, Karl. From Hegel To Nietzsche : The Revolution in Nineteenth-Century Thought. Trans. David E. Green. London: Constable 1965.

Muller, F. Max. Sacred Books of the East. Oxford: Clarendon, 1883-1910, reprinted by Motilal Barnasidas, Delhi, 1962-68.

Otto, Rudolph. The Idea of the Holy. Trans. John Harvey, from the 9th German edition. London: Oxford University Press, 1929.

Smith, William Robertson. Religion of the Semites: The Fundamental Institutions. New York: Schocken, 1972.

Weber, Max. The Protestant Ethic and the Spirit of Capitalism. Trans. Talcott Parsons. London: Routledge, 2001. 